\title{
INPATIENT COSTS IN THE PERSPECTIVE OF POLISH HEALTH POLICY: SCENARIO ANALYSIS
}

Katarzyna M. Miszczyńska, Piotr M. Miszczyński

\section{Abstract}

Constantly growing health needs, changing demographic situation resulting in often prolonged treatment process, technological progress in the field of highly specialised medical procedures and the associated increase in patient awareness translate into an increase in the operating costs of the healthcare sector. The main aim of the study was the assessment of the relationship between the labour costs of medical staff and in-patient curative care costs financed by the main payer over the next decade. The research results confirmed that the assumed increase of expenditures on healthcare sector to the level of 9\% of GDP in 2027 (proposed by management units) is unlikely to happen. The research findings were obtained by the implementation of scenario analysis supported by the development trend analysis.

Keywords: healthcare expenditures, health economics, labour costs, health policy, public sector

JEL Classification: I11, H51, I15, H60, J45

\section{INTRODUCTION}

The healthcare system in Poland is organised mainly on a public basis. In order to improve its performance, the system of managing public healthcare funds is subject to constant transformations. Proper management and use of property of entities of public finance sector have become the most important issue nowadays (Wrona 2011). The necessity of effective spending of public funds is related to the need to ensure the financial security of public finance sector entities, regardless of budget constraints or economic fluctuations. The changes taking place in recent years in the healthcare system have caused some problems in the financial and economic situation of healthcare units. Changes in the methods of financing and the independence of public healthcare facilities played an important role, which, as a consequence, resulted in an increasing responsibility of the managerial board for the financial and operational results (Kogut 2009). Constantly growing healthcare needs, changes in

Katarzyna M. Miszczyńska, PhD

(corresponding author)

Department of Public Finance

Faculty of Economics and Sociology

University of Lodz

Address:

39 Rewolucji 1905 r. Street

90-214 Łódź, Poland

ORCID: 0000-0003-4924-7605

Piotr M. Miszczyński, PhD

Department of Operations Research Faculty of Economics and Sociology

University of Lodz

Orcid: 0000-0001-6959-9427 
demographic situation often resulting in prolonged treatment process, technological progress in the field of highly specialised medical procedures and the associated increase in patient awareness translate into an increase in the cost of healthcare units. All of this entails the need to use methods of rationing the costs of functioning of healthcare entities, and, consequently, improving the efficiency of resource management of public healthcare units. A prerequisite for effective performance of healthcare institutions is the application of good management practices (Cieśla 2012; Griffin 2004). Difficult financial and economic situation of public healthcare units, and the problem of indebtedness, should be one of the most important issues to be solved by public administration. Hospitals that are public health entities are companies that are not subjected to market laws. Due to the fact that public funds constitute the basic source of financing in Poland, health services provided by public entities, both the government, self-governments and other institutions that are their founding bodies, should be interested in the most appropriate way to spend them.

The tense situation on the government - medical workers line has been widely discussed in Poland recently. The strikes of physicians complaining about too low expenditures on healthcare, unfortunately, despite strenuous attempts, adversely affected the well-being of patients. Taking into account insufficient funds for in-patient curative care, the following question arises: will these expenses be shaped in the perspective of the next decade? Therefore, the discussion leads to the following detailed research questions:

1. To what extent will the relationship between the labour costs of medical staff and healthcare system expenditures on in-patient curative care change?

2. Will the relationship between the labour costs of medical staff and expenditures for in-patient curative care change in time?

3. Will the increase in the share of expenditure on health in Gross Domestic Product translate into a relatively larger increase in spending on in-patient curative care?

In the light of the research questions presented, the purpose of the article relates to the assessment of the relationship between the labour costs of medical staff and in-patient curative care costs financed by the National Health Fund in the context of the proposed assumptions of health policy over the next decade. The study was based on the development trends analyses, which were used to present a scenario analysis related to the formation of healthcare expenditures of the main payer of the healthcare sector (National Health Fund). The scenario analysis was based on the recent postulates of the medical community related to the reported needs for increasing the share of public expenditure on health in GDP.

According to the constructed scenarios a scientific hypothesis has been created as follows: the increase in the share of expenditures on healthcare to $9 \%$ of GDP in 2027, as proposed by the state entities, is unlikely to happen.

The article enriches the state of knowledge by identification of trends in the formation of the value of healthcare costs in Poland. What is more, it contributes to better understanding of the assumed changes proposed as part of the health policy.

The remaining part of this article is organised as follows. Section 2 concentrates on literature review on the subject in question. Section 3 discusses the basics of organization and financing of the healthcare sector in Poland. Sections 4 presents the research method, results and undertakes the discussion in the context of formulated aims and research questions. Section 6 presents conclusions.

\section{LITERATURE REVIEW}

The healthcare sector is extremely important in shaping the economic development of the state, as it exerts a significant influence on it through the applied care model. Assessment of healthcare systems is fairly complex and causes numerous difficulties, both interpretative and methodological (Łyszczarz 2014). The efficient functioning of healthcare units turns out to be important not only from the perspective of patient satisfaction, but also from the perspective of the managerial staff. That is why research in this area is conducted by scientists from national centres (Kautsch 2011; Suchecka 2000; Golinowska 2012; Hass-Symotiuk 2011; Austen 2010; Węgrzyn 2012; Miszczyńska 2013) and foreign (among others Jacobs 2001; Rapoport, Jacobs, and Jonsson 2008; Martin, Rice, and Smith 2012; Smith and Topol 2013a; Jones 2009; Rischatsch 2012). Łyszczarz and Nojszewska focus on the healthcare system as a whole, making an in-depth analysis from the point of view of economic theory and the experience of other countries (Łyszczarz and Nojszewska 2017). In studies carried out in foreign centres, a special attention should be paid to the work of Zweifel, Breyer and Kifman (2009) presenting the determinants of health economics, Maynard and Kanavos (2000) focusing on comparative analysis of the functioning of healthcare systems in different countries, Alemi and Gustafson (2006) focusing on the complexity of decision making in healthcare units, Carroll (2009) addressing the subject of 
risk management in healthcare sector organizations, Martin, Rice and Smith dealing with comparative analysis of costs and results of selected healthcare systems (Martin, Rice, and Smith 2012), Vanberkel's group (Vanberkel, Boucherie and Hans 2012) focusing on assessing effectiveness in the context of healthcare resources, and Smith and Topol (2013b) dealing with the subject of costs in healthcare.

Increasing health expenditures and costs in the past decades, among both developed and developing countries, was discussed in the studies of: Bakx, O'Donnell, and van Doorslaer 2016; Newhouse 1977; Culyer 1988; Gerdtham et al. 1998; Gerdtham and Jonsson 1992; Besseling, Shestalova 2011; Panopoulou and Pantelidis 2011; Astolfi, Lorenzoni and Oderkirk 2012; Lago-Penas, Cantarero-Prieto and Blazquez-Fernande 2013; Maisonneuve and Martins 2013; Lorenzoni, Belloni and Sassi 2014; Zhao 2015.

Scenario analysis and cost modelling are in various healthcare systems around the world. The analysis of the formation of healthcare costs is carried out in two ways: in macroeconomic terms, covering the whole system, and in micro terms, from the perspective of a specific disease. From the micro perspective an interesting study was conducted by Freedman et al. (2006) who presented in their study some national estimates of the proportions of hospital inpatient cases and cost for adult, nonmaternal patients who have multiple chronic conditions. Anand, Kranker and Chen estimated the additional hospital costs associated with inpatient medical harms occurring during an index inpatient admission and costs from subsequent readmissions within 90 days (Anand, Kranker and Chen 2019). Spector et al. estimated the hospital marginal cost of a hospital-acquired pressure ulcers for patients who were hospitalised for major surgeries with adjustments to patient characteristics, comorbidities, procedures, and hospital characteristics (Spector et al. 2016). Seghieri, Berta, and Nuti analysed Geographic variation in inpatient costs for Acute Myocardial Infarction care in Italy (Seghieri, Berta and Nuti 2019). What is more, the study of Ashford and Bailey was concerned with the development of a set of statistical models to relate hospital inpatient costs to the resources and activity within specialties in England (Ashford and Bailey 1984).

The literature on the subject also includes research on effective methods used for cost modelling. The study of Deb and Norton (Deb and Norton 2018) is an excellent example of such a study. In their study, they describe estimation and interpretation of the effects of a natural experiment using two classes of nonlinear statistical models: one for healthcare expenditures and the other one for healthcare use. A similar study was undertaken also by Malehi, Pourmotahari and Angali who conducted a simulation study on statistical models for the analysis of skewed healthcare cost data (Malehi, Pourmotahari and Angali 2015). Mihaylova, et al. reviewed statistical methods for analysing healthcare resource use and costs, their ability to address skewness, excess zeros, multimodality and heavy right tails, and their ease for general use. They aimed to provide guidance on analysing resource use and costs focusing on randomised trials, although methods often have wider applicability (Mihaylova et al. 2011). A similar attempt was also made by Gregori et al. (2011) whose article was intended to describe various approaches in multivariable modelling of healthcare costs data and to synthesize the respective criticisms as proposed in the literature. Powers et al. (2005) sought to evaluate several statistical modelling approaches in predicting prospective total annual health costs (medical plus pharmacy) of health plan participants using Pharmacy Health Dimensions (PHD), a pharmacy claims-based risk index. In their research, Olivera and Bevan (2008), applied modelling of hospital costs to produce evidence for policies that promote equity and efficiency. Oker and Ozyapc applied in their study a time-driven activity-based costing system by which managers of hospitals should eliminate the cost of unused capacity so as to obtain better results. Based on the results of the study, the managers can easily notice the cost of unused capacity and decide how many employees should be dismissed or directed to other productive areas (Oker and Ozyapc 2013).

The previous studies conducted in Poland did not analyse the scenario analysis concerning the trends in the healthcare costs creation, in particular in-patient curative care costs, and their links to the gross domestic product in great details. There were also no detailed studies on the impact of the changes in health policy, from the healthcare expenditure perspective, on the functioning of the entire healthcare system, or the benefits provided by hospitals. In the year 2017 an attempt was made by Price Waterhouse Cooper's, at the request of the Polish Ministry of Health, to examine the trends in changes of healthcare costs. However, the study did not present the subject in great details. The authors underlined only that $52 \%$ of all costs were staff costs, costs of external services, including patient nutrition (around $24 \%$ of costs), material costs (about $18 \%$ of costs), costs infrastructure depreciation (about $4 \%$ of costs), management and administration costs (about 2\% of costs), and other costs currently not quantified, e.g. debt service costs. The analysis was summed up with the statement that virtually all costs indicate increasing trends. The highest increase was 
observed in salary costs, which was rational because salaries in Polish healthcare were at a definitely lower level than in others countries. On the other hand, this publication pointed out a number of structural changes to improve the use of funds of the National Health Fund, infrastructure, human resources, including mainly specialists - so that they perform tasks for which they are designated (Pwc 2017). Lenik, Krygowska and Biernacka created a comparison of labour costs in public and non-public hospitals in Poland, and made an attempt to work out conclusions about the causes as well as possible effects of the current state of affairs (Lenik, Krygowska and Biernacka 2017). Czerska made an attempt to build a model of costs of healthcare services of the National Health Fund in Poland taking into account the incidence aspect (Czerska 2015). The analysis of the impact of recent reforms, also in terms of the creation of healthcare costs, has been presented by Sowada and Sagan (2019). Dubas-Jakóbczyk, Kowalska-Bobko, and Sowada presented in their study the principles of the introduction in 2017 in Poland of a system of basic hospital service provision, popularly called the 'hospitals network' and possible effects on the systems financing (Dubas-Jakóbczyk, KowalskaBobko, and Sowada 2019). Pawłowska pointed out in her work some economic, medical and managerial problems related to functioning of public medical institutions and proposed some recommendations on this basis (Pawłowska 2016).

The study conducted in this paper contributes to the existing literature in several important ways. First of all, it analyses the links between in-patient curative care costs and GDP in terms of labour costs which has not yet been the case before. Secondly, it offers the scenario analysis quantifying the government's proposed changes to the size of expenditure on in-patient curative care costs, which has not been undertaken on a large scale either. What is more, the study also shows the value of in-patient curative care costs, labour costs and their share in GDP over the next decade.

\section{POLISH HEALTHCARE SYSTEM - BASICS OF FUNCTIONING}

The healthcare system in Poland is classified as an element of the public finance system. The element that distinguishes it from other sectors of the economy is the presence and the connection of the public and private sectors. The healthcare system is financed from two sources: state budget and the contributions from public health insurance. As Wrona (Wrona et al. 2011) emphasizes, the existence of state entities is inevitable for implementation of the processes at the desired level. In Poland, entities operating in the healthcare sector, i.e. the National Health Fund (main payer of the healthcare system) and independent public healthcare institutions are subject to the provisions of the Act of 27 August 2009 on public finance (Journal of Laws of 2009 No. 157 item 1240). They are entities forming the public finance sector, and thus they perform public tasks and are financed from public funds.

The basic source of healthcare financing in Poland is funds from public health insurance that are at the disposal of the National Health Fund. The insurance premium is paid by every citizen depending on the income. Since 1st January 2007 the health insurance premium has been $9 \%$ of the assessment base $(7.75 \%$ is deducted from income tax and $1.25 \%$ is covered by the insured). Figure 1 presents the development of the premium amount in the years 1999-2019.

According to the Polish Ministry of Health, employees, people conducting business activities, students, children, pensioners, and the unemployed are subject to health insurance. Some part of the contributions is financed by taxes, which means that (Magda and Szczygielski 2011) the state budget pays contributions for students, farmers and their family members; social assistance centers pay contributions for the non-registered unemployed (who meet the income criterion) and labour offices pay contributions for the unemployed. Spending on health protection comes from

Figure 1. Amount of health insurance premium in the years 1999-2019

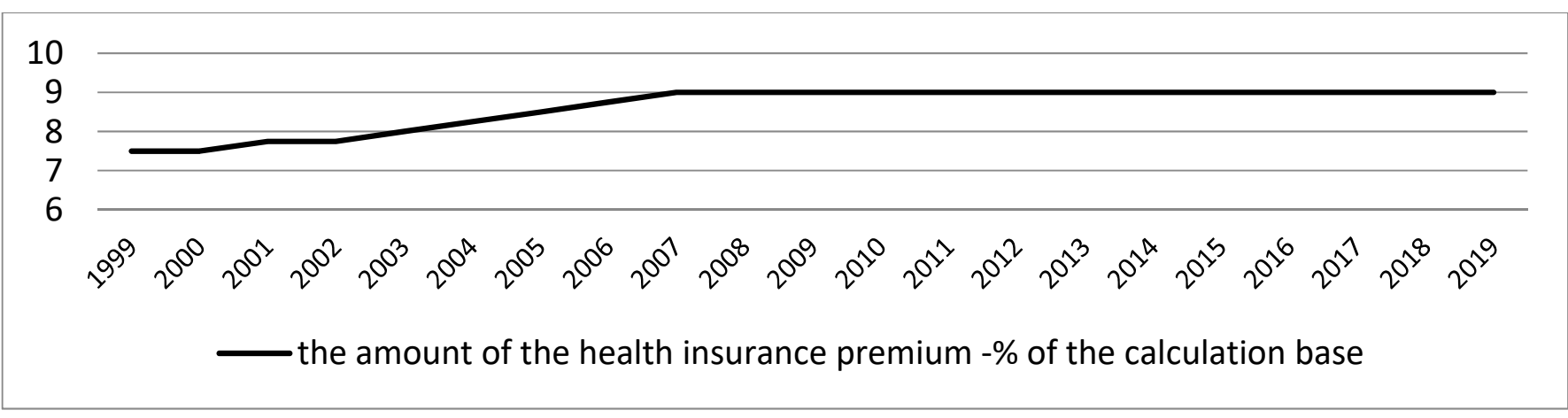

Source: own calculation based on www.zus.pl 
Figure 2. Share of public and private sector expenditures in total health expenditure in 1999-2019

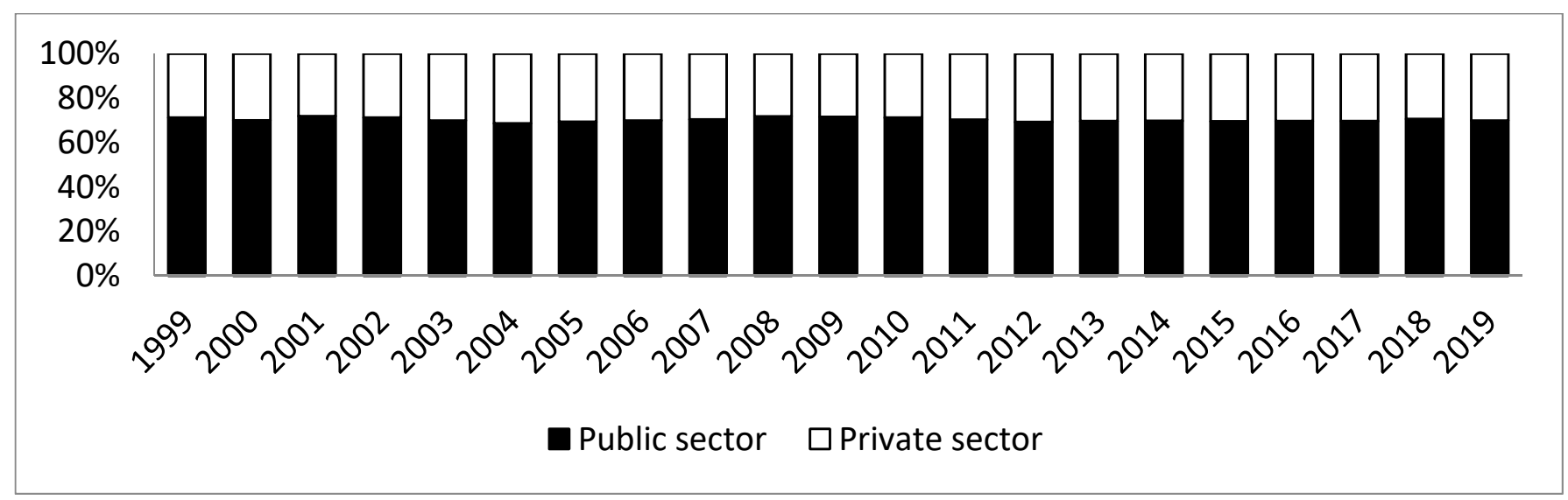

Source: own preparation on the basis of World Bank Statistics: http://data.worldbank.org/country/poland

public funds in $70 \%$, of which more than $80 \%$ is covered by the National Health Fund (see Figure 2).

In the year 2015, the National Health Fund covered $86 \%$ of public expenditures on healthcare (see Figure 3) Compared to $79 \%$ in 2005 . As Golinowska (2012) underlines, the National Health Fund allocates over $95 \%$ of the total revenues from insurance premium for the financing of healthcare services (i.e. for in-patient curative care, basic healthcare, reimbursement of medicines and outpatient healthcare), and the rest of financing for the health programs, emergency medical services and its activities. Moreover, the National Health Fund also finances preventive examinations of its contractors (Ostaszewski 2013). The structure of public expenditure on healthcare in 2015 is presented in Figure 3, however, this structure remains unchanged until 2019.
Health expenditures of the state budget constituted on average $2.4 \%$ of total expenditure in 1999-2019 and it was much less than the state intended, among others, for social expenditures (in 2011 - 5.5\%, in 2010 $5.8 \%$ ) or public administration (in $2013-5.6 \%$, in 2012 - 5.5\%). Expenditure of territorial self-government units was characterised by considerable diversification, with about $6.0 \%$ share of provincial and poviat budgets (2013). The costs of health services for the insured incurred by NHF in 2015 were by 6.8 p.p. higher than in 2014 and reached the level of 67,502 million PLN. What is more, the expenditure on healthcare of state budget constitutes on average $4.3 \%$ of GDP. The most important categories of the cost of health services for the insured incurred by the National Health Fund are presented in Figure 4.

As it was mentioned before, the Polish national

Figure 3. Structure of public expenditure on healthcare in 2015

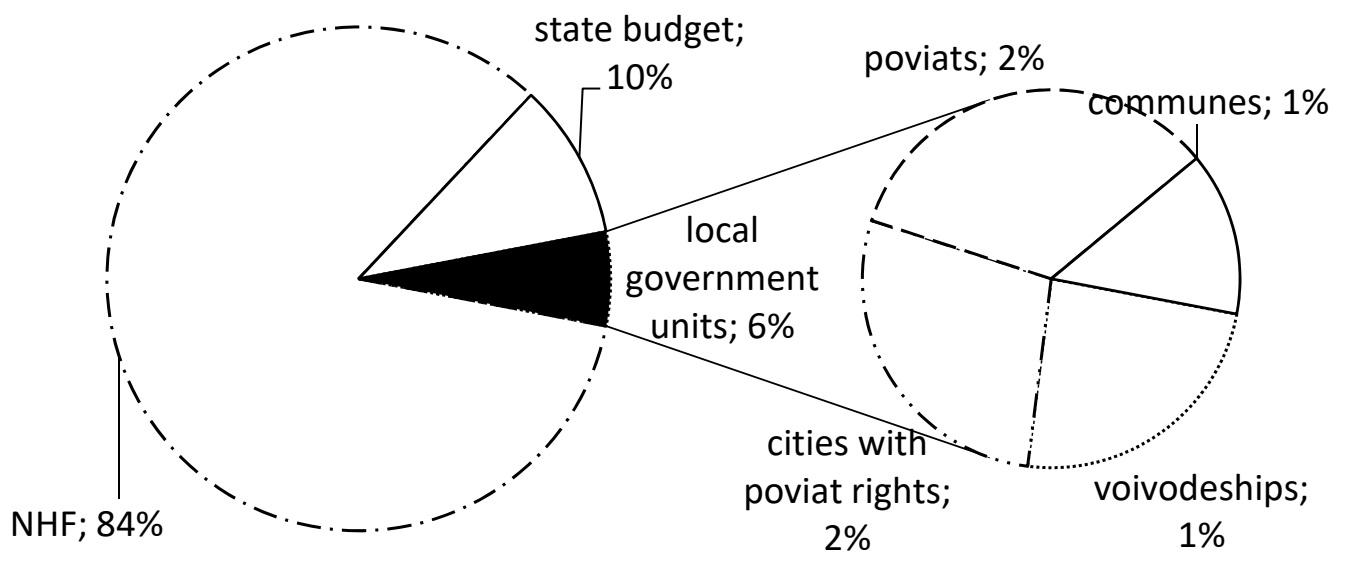

Source: (GUS 2017a) 
Figure 4. Costs of health services for the insured incurred by National Health Fund

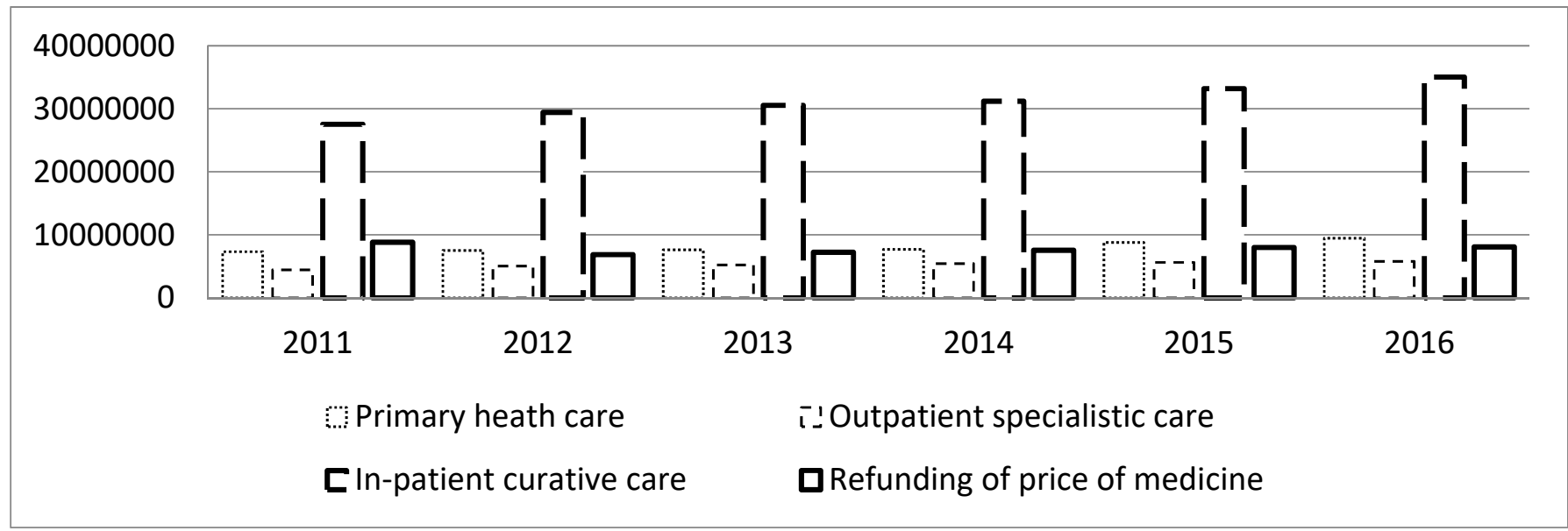

Source: (GUS 2017a)

healthcare system is classified as an element of the public finance system. The presence and connection of the public and private sectors distinguish it from other sectors of the economy. On the one hand, healthcare is financed by the state, and on the other hand, by contributions from public health insurance. As Wrona (2011) emphasizes, the existence of state entities is inevitable for the protection of health, from the perspective of the functioning of the processes at the desired level. In Poland, entities operating in the healthcare sector, i.e. the National Health Fund and public hospitals perform public tasks and are financed from public funds. The majority of hospitals are public units that provide highly specialised procedures. According to the Small Statistical Yearbook of Poland, in 2015 there were 956 general hospitals. In recent years, there has been a noticeable decrease in the number of public facilities, with the simultaneous increase in non-public units. However, it is still public units that constitute the dominant group of medical facilities.

Inpatients, constituting an integral part of the healthcare sector, create its demand side. According to Small Polish Statistical Yearbook (GUS 2017b), 7.8

Figure 5. Number of beds in general hospitals and its inpatients in years 1999-2018

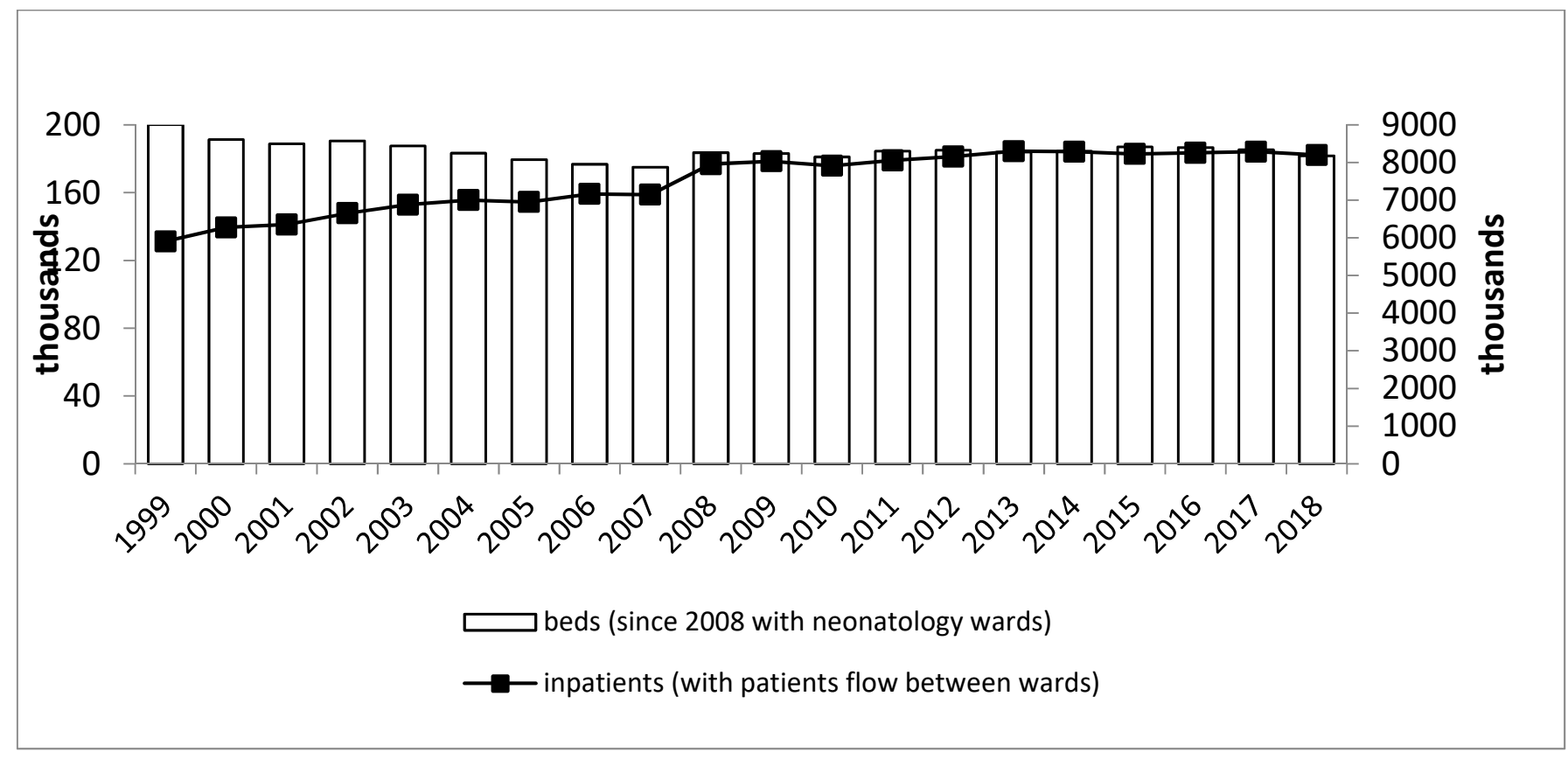

Source: own elaboration on the basis of Central Statistical Office database and Ministry of Health database 
Figure 6. Number of people entitled to practice in the healthcare sector in years 1999-2018

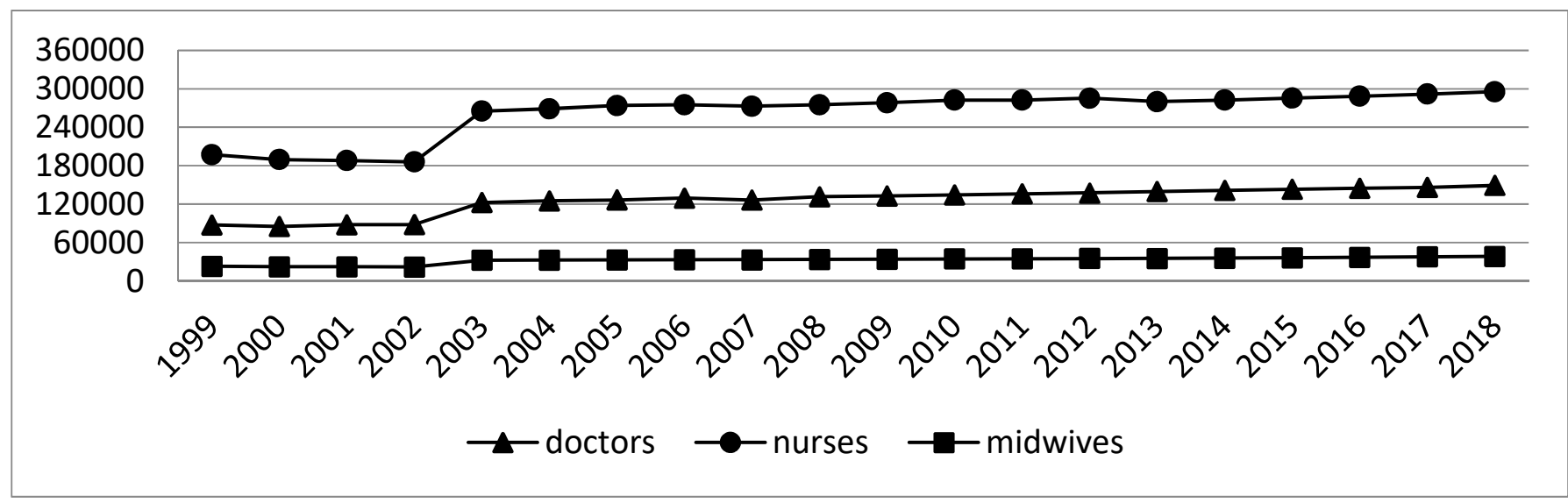

Source: own elaboration on the basis of Central Statistical Office database and Ministry of Health database

million patients were cured in 187.000 hospitals beds (on registered in 2018) in 949 general hospitals (see Figure 5).

The supply in healthcare sector constitutes the providers of medical services. According to Statistical Bulletin of the Ministry of Health (2017) in 2016 149.134 doctors, 41.000 dentists, 295.464 nurses and 38.312 midwives had the right to practice. Figure 6 presents the number of people entitled to practice in the healthcare sector in years 1999-2018.

According to the Ministry of Health studies, no significant fluctuations were observed in the number of medical personnel, according to their basic place of employment. When comparing people entitled to practice (see Figure 6) and working staff, it can be noticed that in years $2003-2019$, around $62 \%$ to $67 \%$ of the people entitled to practice respectively as a doctor, nurse and midwife worked in healthcare facilities.

Taking up the threads of medical personnel working in healthcare facilities, it is also worth considering how the average wage in particular occupational groups was shaped. This is an extremely important aspect, because, according to the findings of the Supreme Audit Office, the remuneration is a dominant part of hospitals expenses, and the remuneration of medical personnel constitutes $80-90 \%$ of the total sum intended for the remuneration. The data on average remuneration were obtained from reports of the Central Statistical Office published every two years. The values of the average remuneration in years not covered by the Central Statistical Office research were determined by means of interpolation. The average remuneration in individual occupational groups illustrates the upward trend (see Figure 7). The gross salary of the doctor more than doubled in 2014 compared to 2004, while midwives and nurses increased almost three times. It is worth mentioning, that until 2008, the CSO report included the average gross remuneration

Figure 7. Average remuneration for doctors and nurses in 2004-2018 [in Polish zloty]

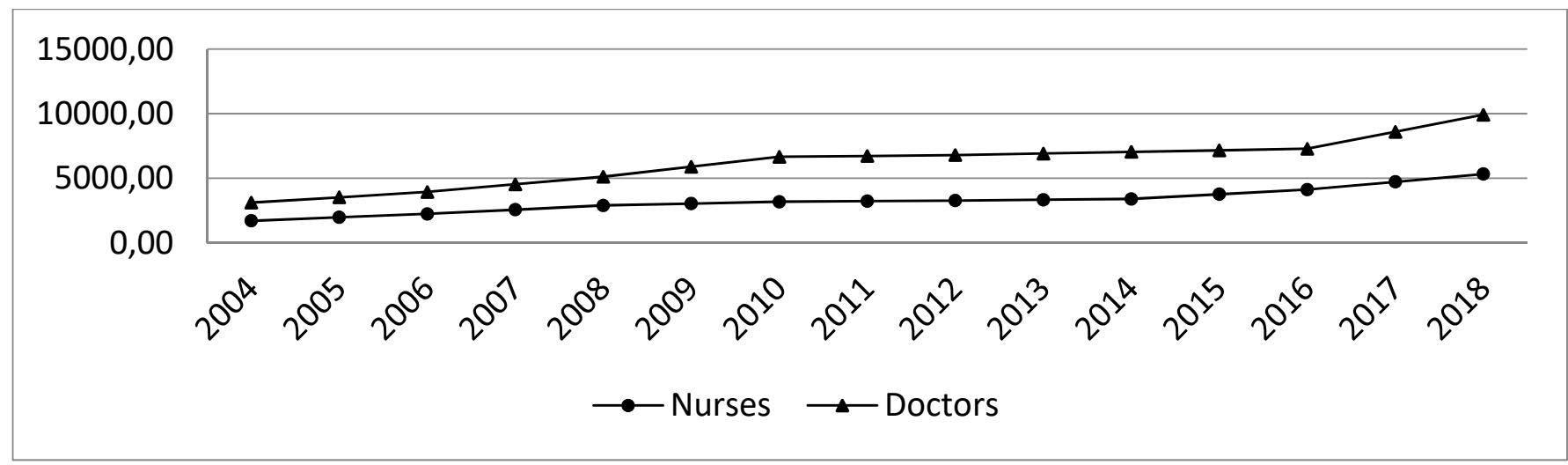

Source: own elaboration on the basis of Central Statistical Office database and Ministry of Health database 
Figure 8. Cost of medical personnel in public hospitals vs. in-patient curative care costs in the years 2005-2018 [constant prices 2005-100]

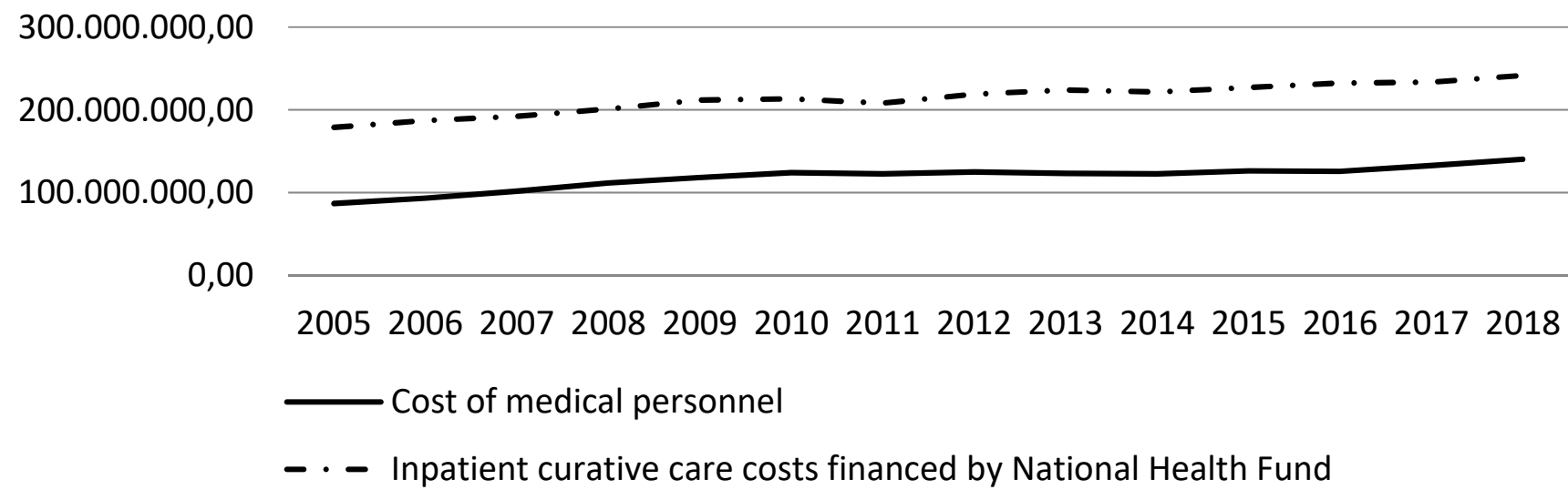

Source: own elaboration on the basis of Central Statistical Office database and Ministry of Health database

of nurses and midwives together. Starting from 2010, these categories have been separated.

Among the costs incurred by National Health Fund for health services, the largest share was inpatient treatment, which since 2004 has shown a continuous upward trend, as well as the average gross remuneration and the number of personnel working in security institutions. However, the growth rate of these categories varied. The wages of medical personnel (doctors, nurses and midwives) increased in the years 2003-2018 by over: 3,5 times for doctors and around 3,9 times for nurses and midwives. At the same time, the number of doctors working in healthcare units increased by $1,8 \%$ and midwives by $4 \%$, while the number of nurses decreased by $4 \%$.

When presenting healthcare financing issues, from the perspective of the main payer it is worth paying attention to the relationship between in-patient curative care costs and medical personnel costs - labour costs (presented in Figure 8).

The financing scheme for inpatient curative care is presented in Figure 9. According to the report of the Supreme Audit Office, the average increase in the remuneration of medical personnel exceeded the average increase in income of hospitals received from contracts concluded with the National Health Fund. It is worth emphasizing that the contract with the National Health Fund makes up about $90 \%$ of all hospital revenues, and the remuneration of personnel is, as the Supreme Audit Office emphasizes, the dominant category of hospital costs.

\section{DATA AND METHODS}

According to the main aim of the article the study was divided into two parts. Firstly, all the necessary forecasts, based on development trend analysis, have been made. In the second part, the scenario analysis has been built. Hence, in order to make predictions concerning the costs of medical personnel and inpatient curative care costs, the development trends in terms of the number of medical staff and their remuneration has been determined. By medical staff we understand the personnel working in the following positions: a doctor, a nurse, a midwife, an emergency worker and a laboratory diagnostician. In order to answer the research questions and verify the research

Figure 9. The NHS healthcare financing scheme

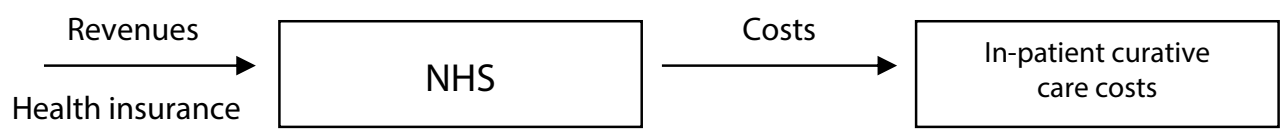

Source: own elaboration 
hypothesis three scenarios have been built: " $\mathrm{A}$ ", " $\mathrm{B}$ " and "O".

Scenario " $A$ " was calculated on the basis of the future changes of GDP. Which means, that the future formation of inpatient curative care costs and the costs of medical staff ware based on the GDP formation.

Scenario "B", was based on the recent postulates of the medical community related to the reported needs for increasing of the share of public expenditure on health in GDP. According to these postulates, the state budget should increase the share of healthcare expenditures to $6.8 \%$ of GDP till the end of the year 2020 and to $9 \%$ of GDP till the end of the year 2027.

The third scenario, scenario "O" ("organic growth"), was made on the basis of the forecasts of the share of public expenditure on health in GDP, which was calculated with the help of trend line.

Moreover, the study was based on the following assumptions:

1. The share of labour costs of medical staff in the in-patient curative care costs is constant. In Poland, this share was within the limits of $48,5 \%$ (in the year 2005) and 57\% (in the year 2017).

2. All the values of the analysed variables have been presented in real terms of fixed prices since the year 2005. This procedure was carried out on the basis of the consumer price index acquired from the Eurostat database.

3. All the predictions were based on the formation of the GDP. Future values of GDP, those between the years 2020-2023 came from the International Monetary Fund. The extension of the GDP forecast to 2029 was based on the development trend line.

4. The changes in the average annual increase in the value of the analysed costs were determined on the basis of CAGR model (1), which can be denoted as follows (Karlson, 2015):

$$
\operatorname{CAGR}\left(t_{0}, t_{n}\right)=\left(\frac{V\left(t_{n}\right)}{V\left(t_{0}\right)}\right)^{\frac{1}{t_{n}-t_{0}}}-1
$$

where, $V\left(t_{n}\right)-$ final value,

$\mathrm{V}\left(\mathrm{t}_{0}\right)$ - initial value,

$t_{0}$ - baseline year,

$t_{n}-$ end of the study year.

The assumptions concerning the future development of medical staff in Poland in the perspective of 2029 were taken from the research carried out by Szcześniak representing the Supreme Chamber of Nurses and Midwives (2011) and Krajewski from the Supreme Medical Chamber (2015).

\section{RESULTS AND DISCUSSION}

\subsection{Empirical results}

The main aim of the study was to assess the relationship between the personnel costs of medical staff and in-patient curative care costs financed by the National Health Fund over the next decade. Thus, the study was carried out in the time horizon 2019-2029 and was based on the development trend analysis, which was used to present a scenario analysis related to the formation of healthcare expenditures of National Health Fund. The scenarios were constructed along the10year period, which seemed to be a sufficiently long period, but not preventing, due to the existing uncertainty, inference. The carried out scenario analysis was based on the recent postulates of the medical community related to the reported needs for increasing the share of public expenditure on health in GDP.

The estimation of the costs of medical personnel was preceded by future formation of the number of doctors, nurses, midwives, emergency workers and laboratory diagnostics. As it was already mentioned, the future development of medical staff was taken from the research carried out by the representatives of the Supreme Chamber of Nurses and Midwives (2013) and the Supreme Medical Chamber (2015). The analysis included the Krajewski (2015) assumption, who assumed that specialists would stop practicing the profession at the age of 70, and new specialists would be arriving at a steady pace. With these assumptions, the number of specializations held in all medical specialties for a total of 10 years will decrease by $3 \%$. However, the total number of specialists, not only having the right to work in their specialty but really working will increase by $10 \%$. This means, that the gap between specialists entitled to practice in the healthcare and those already practicing will decrease. According to the forecasts presented in the study of the representatives of the Supreme Chamber of Nurses and Midwives and the Supreme Medical Chamber, the total number of doctors, nurses, midwives and laboratory diagnosticians will increase by $6,35 \%, 7 \%, 6,4 \%$ and $17,8 \%$ respectively.

As for the formation of the gross average remuneration of all medical specialists, the forecasts were based on the historical data derived from the Polish Central Statistical Office. Figure 10 presents the future trends according to which the highest wage increase recorded between 2003 and 2029 will be of over $40 \%$ at the doctors' level. For nurses, this increase will reach just over $32 \%$, for midwives $31 \%$, and the lowest for laboratory diagnosticians $-11 \%$.

On the basis of all constructed forecasts the scenario analysis has been conducted. The results of the forecasts in all three scenarios are presented in Figure 11. 
Figure 10. The forecasts of the gross remuneration of medical staff (doctors, midwives, nurses, emergency workers) in public healthcare sector in the years 2019-2029 [in PLN]
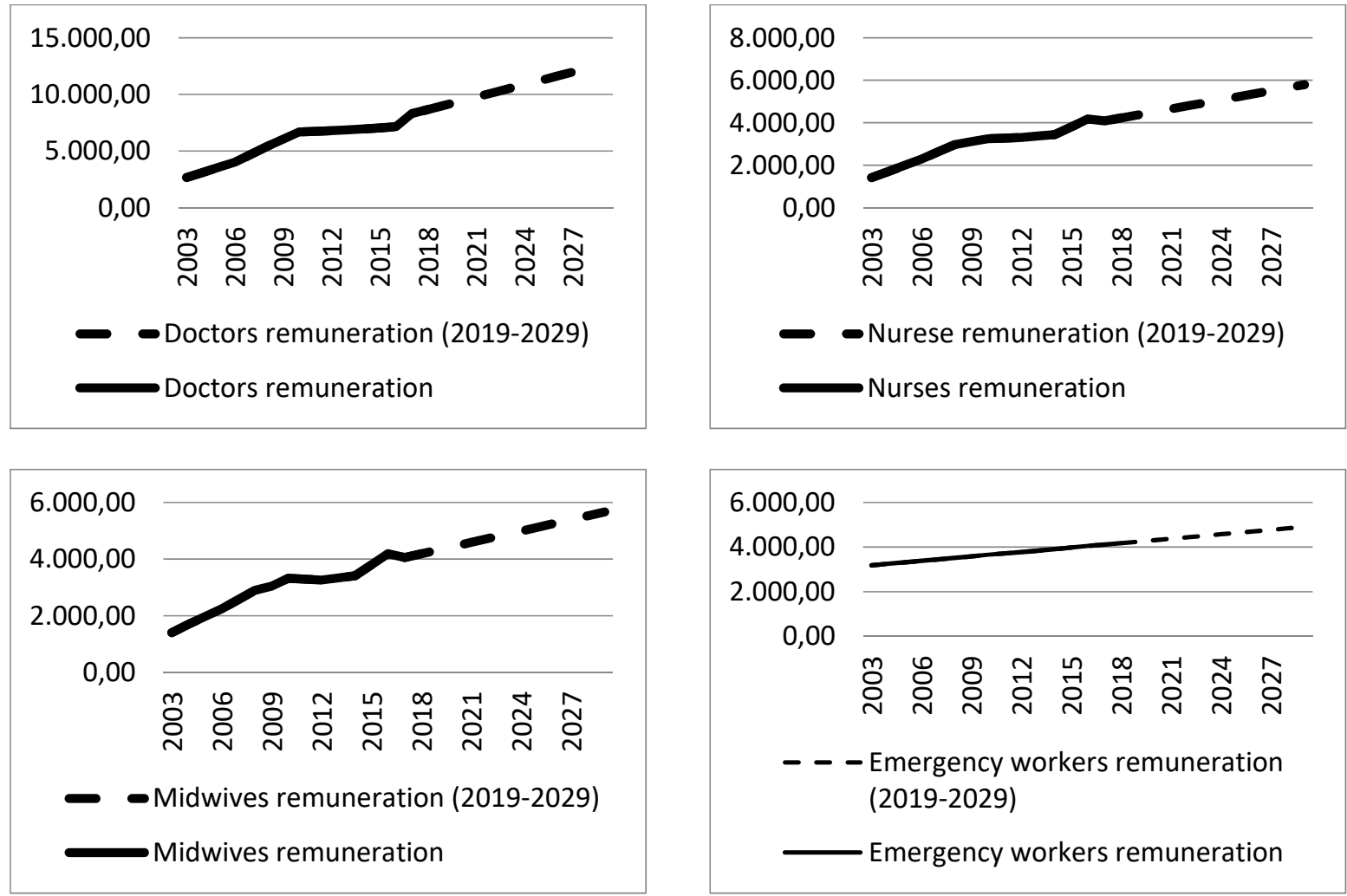

Source: own elaboration

Figure 11. Forecasts of in-patient curative costs and medical personnel costs in the years 2019-2029 [constant prices 2005 $=100, \mathrm{PLN}$ ]

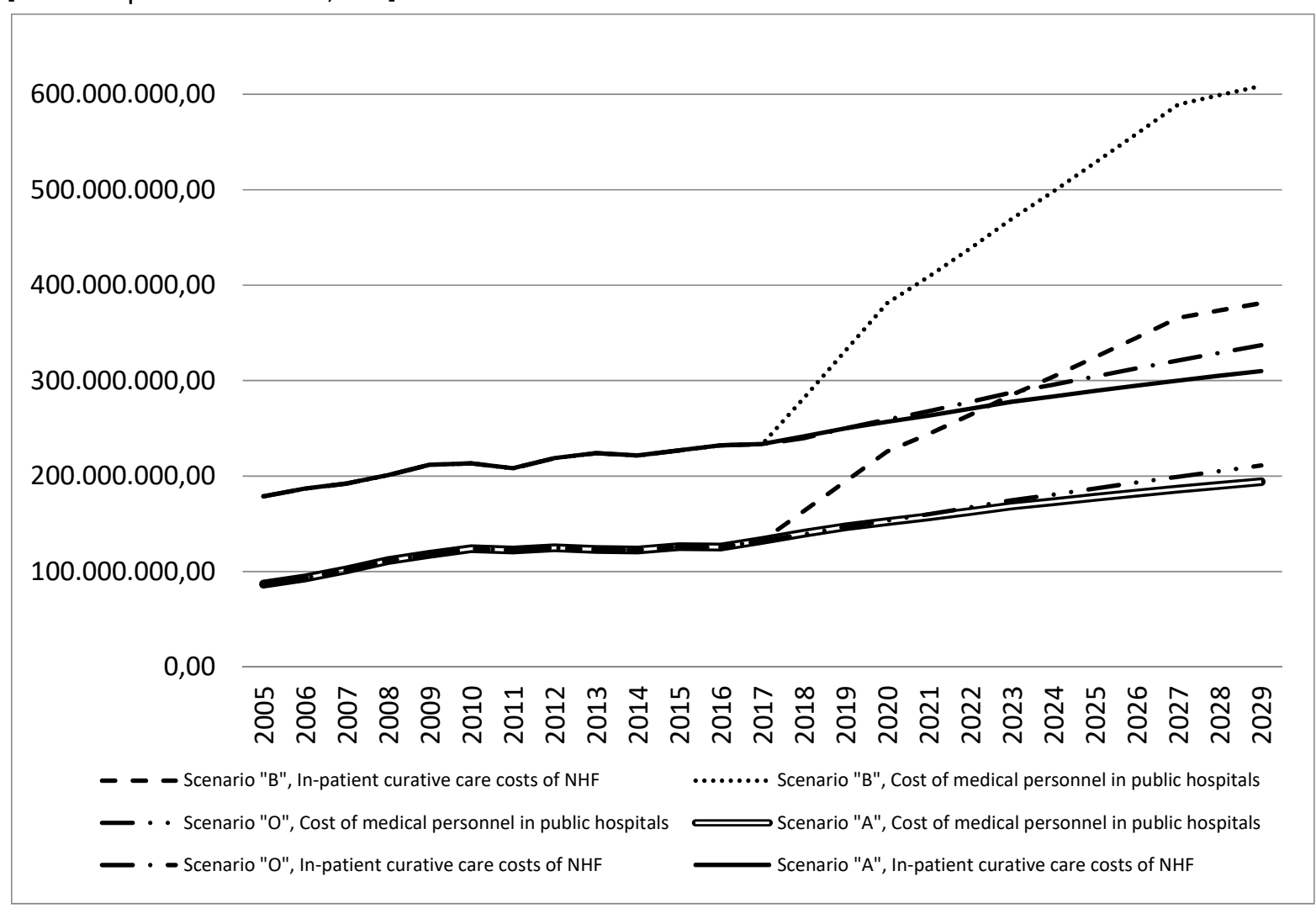

Source: own elaboration 
Table 1. The compound annual growth rate between the years $2005-2029$ vs. Scenarios

\begin{tabular}{|c|c|c|c|c|c|c|}
\hline Scenario & \multicolumn{2}{|c|}{ A } & \multicolumn{2}{c|}{ O } & \multicolumn{2}{c|}{ B } \\
\hline Costs & $\begin{array}{c}\text { Cost of medical } \\
\text { personnel in public } \\
\text { hospitals }\end{array}$ & $\begin{array}{c}\text { In-patient } \\
\text { curative care } \\
\text { costs of NHF }\end{array}$ & $\begin{array}{c}\text { Cost of medical } \\
\text { personnel in } \\
\text { public hospitals }\end{array}$ & $\begin{array}{c}\text { In-patient } \\
\text { curative care } \\
\text { costs of NHF }\end{array}$ & $\begin{array}{c}\text { Cost of medical } \\
\text { personnel in } \\
\text { public hospitals }\end{array}$ & $\begin{array}{c}\text { In-patient } \\
\text { curative care } \\
\text { costs of NHF }\end{array}$ \\
\hline CAGR & $3,42 \%$ & $2,32 \%$ & $3,78 \%$ & $2,68 \%$ & $6,37 \%$ & $5,24 \%$ \\
\hline
\end{tabular}

Source: own elaboration

According to the scenario analysis, the value of funds for healthcare and, in particular, for hospital treatment (inpatient costs) will change. From the results presented in the chart below, it can be seen that Scenario B seems to be highly unlikely. The increase in the share of expenditure on healthcare postulated by healthcare workers, from approx. $4 \%$ of GDP to $9 \%$ in 2027, seems unachievable in such a short time. The increase in spending on healthcare seems more likely to occur on the basis of forecasts based on the current increase in the share of these expenditures in GDP. Scenario A is the scenario in the "minimum" version, i.e. assuming an increase in the cost of hospital treatment (inpatient costs) and an increase in the cost of medical personnel according to GDP changes.

In order to complete the analysis, a model of the CAGR (Compound Annual Growth Rate) was used (see Table 1). Based on the analysis carried out, in the perspective of 2005-2029, the cumulative annual growth rate of costs of medical staff exceeded the average annual growth rate of in-patient curative care costs financed by the National Health Fund in all the analysed scenarios. Such a situation will always occur because the costs of medical personnel are strongly correlated with the costs of hospital treatment (Pearson's correlation coefficient $=99 \%$ ).

\subsection{Discussion}

Concluding the considerations regarding the in-patient curative care in the years 2003-2017, two questions will have to be answered. First of all, what were the consequences for the patients in terms of the financial situation of the healthcare sector? What was the hospital situation like? Firstly, from the point of view of the patient, hospital care costs funded by the main payer increased approximately twice in the period considered, it would be beneficial to patients if this increase could result from a significant increase in the procedures performed. However, this was not the case, as the observed increase in financial resources was almost entirely consumed by the increase in wages (with almost unchanged employment), which in combination with the introduction of new technologies (more effective, but very expensive) meant an increase in financial resources not reflecting on improving the patient's situation.

From the hospital's perspective, the dominant share of labour costs (about $90 \%$ is the salary of medical staff, which is mostly paid for readiness) and observation that the CAGR increase in labour costs was bigger than the increase in costs of hospital treatment financed by the National Health Fund may lead to financial problems of hospital. The increase in remuneration is correlated with the amount of money in the system. These two variables grew proportionally. The assumption adopted in the study about the stability of the relationship between the labor costs of medical staff and the in-patient curative care costs was the assumption of a strong but confirmed system practice. It will always be the case that most of the funds will be spent on salaries. The postulates of employees in the healthcare sector, which are the basis for the " $\mathrm{B}$ " scenario, assumed that with the increase in expenditure on healthcare, measured by their share in GDP, there will be an increase in expenditure on hospital treatment. Of course, assuming scenario " $\mathrm{B}$ ", the system will see more funds, but due to the fact that the amount of these funds is strongly correlated with wages, wage pressures will lead to a proportional increase in wages, not expenditures on hospital treatment. Thus, the growth rate of these variables will not relatively change.

On the basis of the scenario analysis, it can be concluded that the " $\mathrm{B}$ " scenario is very unlikely to be realised. The basic problem of the assumptions of this scenario, from the perspective of the state budget, was far too big surplus of funds, in comparison with the planned GDP growth, in a relatively short time. In addition, as the data and dependencies from 2003-2018 show, the share of labour costs of medical staff in the cost of treatment was relatively stable. There was no decrease in this share with the increase in expenditure on healthcare. In other words, an increase in outlays on healthcare will also cause wage pressure and will maintain the assumed share. 


\section{CONCLUSIONS AND RECOMMENDATIONS}

In the literature on the subject, there is a general statement that the functioning of the healthcare sector in Poland is far from satisfactory. This claim is confirmed by the research conducted on national and international level. According to Price Waterhouse Cooper's report the healthcare costs will increase, some at a much faster pace than the increase in investment in health protection. As a result, increase in the financing without major reforms will not improve the situation, including availability and improvement of service quality. This was also confirmed by the results of the study.

The funding shortage was and will remain the fundamental problem in the healthcare sector. What is more, the increase in the level of funding would not resolve the problems. An increase in efficiency is highly required in the system. Proper management is also needed for the protection of health measures, key identification of areas requiring investment or development in the medium and long term, and meeting the constantly rising patients' expectations. It is important to precede the reforms by: in-depth analysis of the existing state of affairs, defining some strategic goals, actions taken and working out practical monitoring solutions and correcting their implementation. The obtained results showed some implications of proposed by public authorities assumptions, concerning the development of health policy in Poland. In order to improve the functioning of the healthcare system in Poland, it is also necessary for the healthcare sector to cooperate with other sectors (social policy and labour market sectors), ensuring harmonization of tasks and their more effective implementation. This premise also corresponds to the results of Pawłowska research.

In the future, the authors will deepen the topic of financing the healthcare sector by using advanced scenario analysis methods and taking into account other factors affecting the health policy of the state. Thus, the study presented in the article should be treated as a preliminary stage to the extended health policy modelling.

\section{ADDITIONAL INFORMATION ACKNOWLEDGEMENTS}

This article is an output from the research project Multicriteria assessment of efficiency of public hospitals in Poland and identification of determinants of their indebtedness financed by the National Science Centre, decision number DEC-2016/23/N/HS4/03410

\section{DISCLOSURE STATEMENT}

No potential conflict of interest was reported by the authors.

\section{REFERENCES}

Alemi, F. \& Gustafson, D.H. 2006. Decision Analysis for Healthcare Managers. Chicago: Health Administration Press.

Anand, P., Kranker, K. \& Chen, A. 2019. Estimating the Hospital Costs of Inpatient Harms. Health Services Research, 54 (1): 86-96.

Ashford, J.R. \& Bailey, T.C. 1984. A Model of Hospital Inpatient Costs: A Statistical Approach Based Upon an Analysis of Cost Components and an Implementation as Part of a Management Decision Support System. In Hird International Conference on System Science in Health Care. Health Systems Research, 694-97. Springer.

Astolfi, R., Lorenzoni, L. \& Oderkirk. J. 2012. A Comparative Analysis of Health Forecasting Methods. OECD Health Working Papers No. 59: 0-120.

Austen, A. 2010. Pomiar Efektywności w Organizacjach Ochrony Zdrowia. In Pomiar Efektywności Organizacji Publicznych Na Przykładzie Sektora Ochrony Zdrowia, edited by A. Frączkiewicz-Wronka. Prace naukowe Akademii Ekonomicznej im. Karola Adamieckiego we Wrocławiu.

Bakx, P., O. O'Donnell \& van Doorslaer, E. 2016. Spending on Health Care in the Netherlands: Not Going So Dutch. Fiscal Studies 37 (3-4): 593-625.

Besseling, P. \& Shestalova, V. 2011. Forecasting Public Health Expenditures in the Netherlands. The Netherlands Bureau for Economic Policy Analysis. 2011.

Carroll, R. 2009. Risk Management Handbook for Healthcare Organisations. American Society for Healthcare Risk Management. Wiley.

Cieśla, K. 2012. Ład Finansowy i Ekonomiczny Podstawą Efektywności Zakładów Opieki Zdrowotnej. In Racjonalizacja Kosztów w Ochronie Zdrowia, edited by Ewelina Nojszewska, 75-80. Warszawa: Wolters Kluwer.

Culyer, T. 1988. Health Care Expenditures in Canada: Myth and Reality; Past and Future. Toronto: Canadian Tax Foundation.

Czerska, I. 2015. Modeling of Health Care Services Costs of the National Health Fund. Scientific Papers University of Szczecin 73 (854): 949-958.

Deb, P. \& Norton, E.C. 2018. Modeling Health Care Expenditures and Use. Annual Review of Public Health 39 (1): 489-505.

Dubas-Jakóbczyk, K., Kowalska-Bobko, I. \& Sowada, Ch. 2019. The 2017 Reform of the Hospital Sector in Poland - The Challenge of Consistent Design. Health Policy 123 (6): 538-43. 
Friedman, B., Jiang, H., Elixhauser, A. \& Segal, A. 2006. Hospital Inpatient Costs for Adults with Multiple Chronic Conditions. Medical Care Research and Review 63 (3): 327-46.

Gerdtham, U.G. \& Jonsson, B. 1992. International Comparisons of Health Care Expenditure - Conversion Factor Instability, Heteroscedasticity, Outliers and Robust Estimators. Journal of Health Economics 11 (2): 189-97.

Gerdtham, U.G., Jonsson, B., Macfarlan, N. and Oxley, H. 1998. The Determinants of Health Expenditure in the OECD Countries: A Pooled Data Analysis. Developments in Health Economics and Public Policy 6: 113-34.

Golinowska, S. 2012. Poland. A Draft of Healthcare System. European Observatory on Health Systems and Policies.

Gregori, D., Petrinco, M., Bo, S., Desideri, A., Merletti, F. and Pagano, E. 2011. Regression Models for Analyzing Costs and Their Determinants in Health Care: An Introductory Review. International Journal for Quality in Health Care 23 (3): 331-41.

Griffin, R.W. 2004. Fundamentals of Organization Management. Warsaw: PWN.

GUS. 2017a. Health and Health Care in 2015 Central Statistical Office of Warsaw: GUS.

Griffin, R.W. 2017b. Small Statistical Yearbook of Poland. Warsaw: GUS.

Hass-Symotiuk, M. 2011. System Pomiaru i Oceny Dokonań Szpitala. Warsaw: Wolters Kluwer.

Jacobs, R. 2001. Alternative Methods to Examine Hospital Efficiency: Data Envelopment Analysis and Stochastic Frontier Analysis. Health Care Management Science 4 (2): 103-15.

Jones, A.M. 2009. Panel Data Methods and Applications to Health Economics. Palgrave Handbook of Econometrics: Applied Econometrics 2:557-631.

Kautsch, M. 2011. Cele Systemu Ochrony Zdrowia a Efektywność w Ochronie Zdrowia w Polsce. Problemy Zarządzania 9 (3): 62-78.

Kogut, J. 2009. Cost Information System in a Public Health Care Facility. In Resources and Processes in Business Accounting, edited by Kiziukiewicz, T. Warsaw: Difin.

Krajewski, R. 2015. There Are Not Enough Doctors, and There Will Be Even Fewer. The Supreme Medical Chamber. 2015.

Lago-Penas, S., Cantarero-Prieto, D. \& Blazquez-Fernande, C. 2013. On the Relationship Between GDP and Health Care Expenditure: A New Look. Economic Modelling 32: 124-29.

Lenik, P., Krygowska, K. \& Biernacka, M. 2017. Problems of Work Costs in the Health Care Sector - Perspectives of Public Hospitals and Non-Public Hospitals. http://82.177.204.10/gfx/pwszkrosno/pl/defaultopisy/1155/5/1/7._problematyka_kosztow_pracy_wsektorze_ochrony_zdrowia.pdf (accessed October 4,2020).
Lorenzoni, L., Belloni, A. \& Sassi, F. 2014. Health-Care Expenditure and Health Policy in the USA Versus Other High-Spending OECD Countries. The Lancet 384: 83-92.

Łyszczarz, B. 2014. Ocena Efektywności Systemów Opieki Zdrowotnej w Krajach OECD. Warszawa: Wolters Kluwer.

Łyszczarz, B. \& Nojszewska, E. 2017. Productivity Losses and Public Finance Burden Attributable to Breast Cancer in Poland. BMC Cancer.

Magda, I. \& Szczygielski, K. 2011. Assessment of the Possibilities of Improving the Operation of the Polish Healthcare System. Co-Payment and Private Health Insurance. Warsaw: E\&Y.

Maisonneuve, Ch. \&Martins, J. 2013. Public Spending on Health and Long-Term Care: A New Set of Projections. OECD Economic Policy Paper Series.

Malehi, AS., Purmotahari, F. \& Angali, K.A. 2015. Statistical Models for the Analysis of Skewed Healthcare Cost Data: A Simulation Study. Health Economics Review 5 (1).

Martin, S., Rice, N. \& Smith, P.C. 2012. Comparing Costs and Outcomes across Programmes of Health Care. Health Economics 21 (3): 317-37.

Maynard, A. \&Kanavos, P. 2000. Health Economics: An Evolving Paradigm. Health Economics 9 (3): 183-90.

Mihaylova, B., Briggs, A., O'Hagan, A. Thompson, S.G. 2011. Review of Statistical Methods for Analysis Healthcare Resources and Costs. Health Economics 20: 897-916.

Miszczyńska, K. 2013. Costs and Revenues of NFZFunctioning in Poland in 2008-2011, with Particular Emphasis on Voivodship Branches. Journal of Management and Finance 11 (2): 161-72.

Newhouse, J. 1977. Medical Care Expenditures: A CrossNational Survey. Journal of Human Resources 12: 115-52.

Oker, F. \& Ozyapc, H. 2013. A New Costing Model in Hospital Management: Time-Driven Activity-Based Costing System. The Health Care Manager 32 (1): 23-36.

Oliveira, M. \& Bevan, G. 2008. Modelling Hospital Costs to Produce Evidence for Policies That Promote Equity and Efficiency. European Journal of Operational Research 185 (3): 933-47.

Ostaszewski, J. 2013. Finance. Warsaw: Difin.

Panopoulou, E. \& Pantelidis, T. 2011. Convergence in Per Capita Health Expenditures and Health Outcomes in the OECD Countries. Applied Economics 44: 3909-3920.

Pawłowska, E. 2016. Economic , Medical and Management Problems Related with Functioning of Public Health Care Institution. Organization \& Management Scientific Quarterly 1: 101-10.

Powers, Ch., Meyer, Ch., Roebuck, M. \& Vaziri, B. 2005. Healthcare Costs Using Pharmacy Claims Data: A Comparison of Alternative Econometric Cost Modeling Techniques. Medical Care 43 (11): 1065-72.

Pwc. 2017. "Trends in Polish Healthcare in 2017. https:// www.pwc.pl/pl/pdf/9-trendow-w-ochronie-zdrowia2017-pwc.pdf (accessed October 4, 2020). 
Rapoport, J., Philip J. \& Jonsson, E. 2008. Cost Containment and Efficiency in National Health Systems: A Global Comparison. Wiley-Blackwell.

Rischatsch, M. 2012. Provider and Consumer Preferences in Healthcare Markets. University of Zurich, Faculty of Economics.

Seghieri, C., Berta, P. \& Nuti, S. 2019. Geographic Variation in Inpatient Costs for Acute Myocardial Infarction Care: Insights from Italy. Health Policy 123 (5): 449-56.

Smith, J. \& Topol, E. 2013a. A Call to Action: Lowering the Cost of Health Care." American Journal of Preventive Medicine 44 (1): S54-57.

Smith, J. \& Topol, E. 2013b. A Call to Action. Lowering the Cost of Health Care. American Journal of Preventive Medicine 44.

Sowada, Ch., \& Sagan, A. 2019. Health Systems in Transition Poland Health System Review 21 (1).

Spector, W., Limcangco, R., Owens, P. \& Steiner, C.A. 2016. Marginal Hospital Cost of Surgery-Related HospitalAcquired Pressure Ulcers. Med Care 54 (9): 845-51.

Suchecka, J. 2000. Nierównomierności w Finansowaniu i Dostępności Świadczeń Medycznych. Warszawa: GUS. https://stat.gov.pl/cps/rde/xbcr/gus/POZ_ Nierownomiernosci_w_finansow_i_dostep__swiad_ medycznych.pdf (accessed October 4, 2020).

Szcześniak, R. 2011. Analiza Liczby Zarejestrowanych i Zatrudnionych Pielęgniarek i Położnych w Roku 2011 oraz Prognoza Liczby Zarejestrowanych i Zatrudnionych Pielęgniarek i Położnych Na Lata 2015-2035. Warsaw.

Vanberkel, P.T., Boucherie, R.J. \& Hans, E.W. 2012. Efficiency Evaluation for Pooling Resources in Health Care. OR Spectrum 34: 371-90.

Węgrzyn, M. 2012. Increasing Funding Sources for Polish Healthcare - Needs and Opportunities. In Health Care. Economic Issues, edited by I. Rudawska, I. \& Urbańczyk, E. Warsaw: Difin.

Wrona, B. 2011. State Regulatory Activities in the Area of Financing Health Care Protection Changes. Scientific Papers of Polish Economic Society 11: 379-95.

Wrona, W. 2011. Regulatory Activity of the State in the Sphere of Financing Healthcare. Polish Economic Society Scientific Notebooks 11.

Wrona, W., Jakubczyk, M., Hermanowski, T., Golicki, D., Czech, M., Niewada, M. \& Kolasa, K. 2011. Cost of Lost Productivity in Pharmacoeconomics Analysis. Part II. Survey in the Expert Group. Epidemiological Review 65(1): 153-57.

Zhao, J. 2015. Forecasting Health Expenditure: Methods and Applications to International Databases. Chepa Working Paper Series Paper, 15-05.

Zweifel, P., Breyer, F. \& Kifman, M. 2009. Health Economics Second edition. Springer. 